\title{
Chlorine, sulfur and oxygen isotopic constraints on ancient evaporite deposit in the Western Tarim Basin, China
}

\author{
Hongbing Tan, ${ }^{*}$ Haizhou Ma, Haizhen Wei, JianXin Xu and Tingwei Li \\ Institute of Salt Lakes, Chinese Academy of Sciences, Xining 810008, China
}

(Received September 25, 2005; Accepted July 14, 2006)

\begin{abstract}
From the late Cretaceous to the early Tertiary period, the Tethys seawater repeatedly invaded the Shaqa sub-basin and entered the Kuqa sub-basin through the Awati straight. At the same time, as a result of tectonic and paleoenvironmental conditions, many sequences of thick strata of evaporites, especially in its two largest sub-basins of Kuqa in the north and Shaqa in the southwest have been deposited. Therefore, the western Tarim Basin has been considered to be a favorable location to prospect for ancient potash deposits. In order to clearly distinguish between a marine or a continental origin, and also to study the evaporite facies (i.e., late vs. early stage), we analyzed the late stages of evaporites of gypsum and salt minerals and measured chlorine isotope values in halite, sulfur isotopes in gypsum and oxygen isotopes in crystalline water of gypsum. The results showed that the sulfur isotope composition of gypsum can be used to distinguish between a marine and continental origin and chlorine isotopes of salt and oxygen isotopes of crystalline water in gypsum can be used to judge the sedimentary stage. Based on these results, we conclude that the late Cretaceous halite deposited in the Kashi Depression of the southwestern Tarim Basin have a marine origin and represent a later stage of marine evaporite sequence compared to other evaporites in the regions. Hence, the Kashi Depression should be considered as a promising area for finding new sylvinite deposits.
\end{abstract}

Keywords: Tarim Basin, salt, isotope geochemistry, sedimentary facies, sedimentary stage

\section{INTRODUCTION}

The Tarim Basin, the largest basin in China, contains a wealth of mineral resources. It not only stores many kinds of metal resources but also nonmetal resources such as ancient salt rock. Many scientists think that it is also a promising area in which to find large ancient potash deposits, but as yet, potash deposit exploration-oriented research work has not made great progress. Many questions, such as whether the deposits represent a marine or continental facies and the sedimentary stage of the salt rocks, are unanswered. The geological setting of the basin and the characteristics of its sedimentary facies are the key factors in deciding whether the basin likely accumulates potash deposits because only sea water can provide enough potassium to produce a huge potash deposit during persistent and continuous evaporation. In addition, the brine must have evaporated to reach the late stage of sylvinite precipitation and must have continued to concentrate the salts for a long time. Overall, the geological characteristics of the Tarim Basin suggest it is a prospective area in which to find potash deposits (Zhen et al., 1974). Hence, it is necessary to determine the sedimen-

*Corresponding author (e-mail: tan72815@yahoo.com.cn) Copyright $\odot 2006$ by The Geochemical Society of Japan. tary facies and stage of salt rock deposited at different times and in different areas in order to evaluate the potential of potash deposits in the western Tarim Basin.

According to statistics for world potash deposits, 90 percent of large-scale ancient potash deposits were formed in marine strata or marine basins because sea water is a major factor in the formation of potassium deposits in nature. Moreover, potassium does not precipitate until the end of the sedimentary stage in which sylvinite or carnallite minerals separate out from highly concentrated brine. Therefore, the marine environment accumulates much larger potash deposits than is possible in the continental facies. Wide and thick strata of ancient salt rock were deposited from repetitive invasion of sea water into the Tarim Basin (Hao et al., 1988). Thus, if we can clearly determine the sedimentary facies of ancient salt rock in space and time, and find the section or strata corresponding to the late stages of salt rock deposition, it will be possible to evaluate the conditions of potash deposit formation in the western Tarim Basin.

In general, the $\mathrm{Br} \times 10^{3} / \mathrm{Cl}$ ratio of salt rock, has long been used to help define the sedimentary stage of the original brines from which salt rocks deposited during evaporation (Bloch and Schnerb, 1953; McCaffrey et al., 1987). For marine salts, with high contents of bromine, it is a useful index of the stage of salt rock deposition, but for continental or mixed origin salt rocks with low contents 


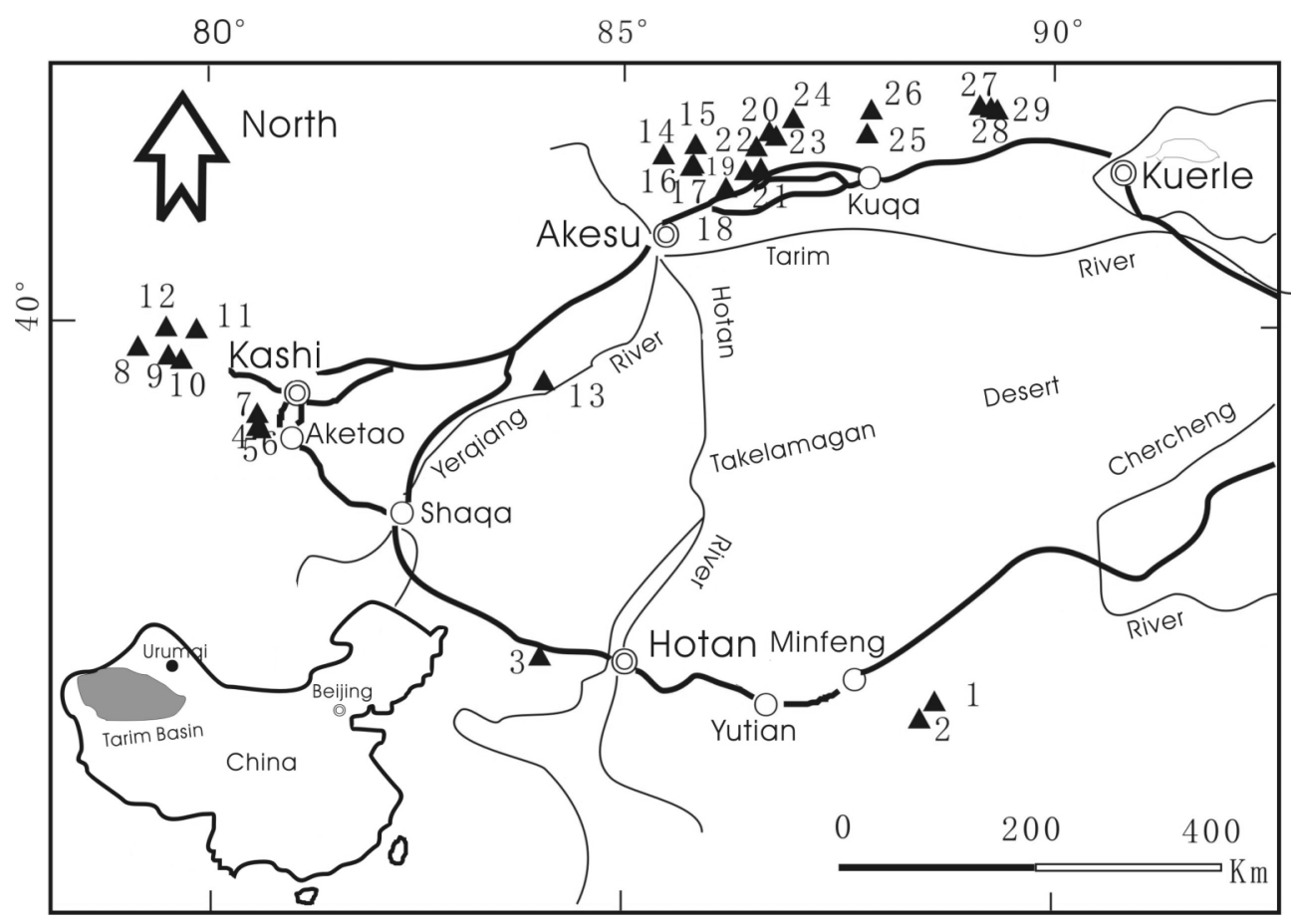

Fig. 1. Map of salt mineral sections surveyed in the field (A Name of salt mineral sections: 1 Kuyake I; 2 Kuyake II; 3 Duwa; 4 Kuluoger; 5 Shaman; 6 Yingjisha; 7 Tashimilike; 8 Kuoshitashi; 9 Maerkanqiati; 10 Aoyikumu; 11 Wukeshalu; 12 Wulukeqiati; 13 Yanshan; 14 Tagelake; 15 Baozidun; 16 Yanshankou; 17 Yanshuigou; 18 Misikantake; 19 Qerqi; 20 Hongshan; 21 Wenbashi; 22 Dawanqi; 23 Tuzimaza; 24 Kumushibulake; 25 Kangcunxi; 26 Basijiqike; 27 Tuzimaza; 28 Luntai; 29 Yangxia).

of bromine, such as those in the Tarim Basin (Tan et al., 2005), its application is more difficult. Hence, this paper, examines the isotopic composition of ancient salt rock in an attempt to examine whether new indexes can be used to study potash deposits and then be utilized to prospect for new potash deposits in the western Tarim Basin.

Firstly, according to research results for sulfur of Cretaceous Maha Sarakham gypsum in the Khorat Plateau of northeastern Thailand, the $\delta^{34} \mathrm{~S}$ values of marine gypsum are $>15 \%$, while mixed facies (marine and continental) have values between $10 \% o$ and $15 \%$ and continental facies are $<10 \%$ (Wedepohl, 1978; Mekhtieva, 1980). Since the Cretaceous to the Present, we know that the secular variations in $\delta^{34} \mathrm{~S}$ values in seawater all are $>16 \%$ and changes between 16 to 22\%o (Paytan et al., 1998, 2004). Therefore, the composition of sulfur isotopes in gypsum should mainly be determined by the source. This can be utilized to discriminate marine evaporites from continental ones.

Secondly, there are two main types of chlorine isotopic fractionations in nature: (1) Different rates of ${ }^{35} \mathrm{Cl}$ vs. ${ }^{37} \mathrm{Cl}$ diffusion results from their mass difference. For example, during diffusion, ${ }^{35} \mathrm{Cl}$ diffuses more quickly than ${ }^{37} \mathrm{Cl}$ resulting in a lower $\delta^{37} \mathrm{Cl}$ in the direction of diffusion (Philips and Bentley, 1987); (2) With respect to ${ }^{35} \mathrm{Cl}$, ${ }^{37} \mathrm{Cl}$ always preferably enters solid salt sediments due to the fact that chemical binding energy of ${ }^{37} \mathrm{Cl}$ is stronger than that of ${ }^{35} \mathrm{Cl}$ during the process of brine evaporation and salt precipitation. Therefore, late stage salt minerals have smaller or more negative $\delta^{37} \mathrm{Cl}$ values. According to research on evaporating experiments for salt lake brines in the Qaidam Basin, China (Liu et al., 1997; Xiao et al., 1999), the ratio of ${ }^{37} \mathrm{Cl} /{ }^{35} \mathrm{Cl}$ becomes lower in residual brine and the $\delta^{37} \mathrm{Cl}$ values become more negative for salts precipitating from brine after continued evaporation and condensation. Eggenkamp and Kreulen (1995) studied chlorine isotope fractionation between $\mathrm{NaCl}, \mathrm{KCl}$, and $\mathrm{MgCl}_{2} \cdot 6 \mathrm{H}_{2} \mathrm{O}$ and their saturated solutions. The results showed that $\delta^{37} \mathrm{Cl}$ of the precipitate decreased systematically during the main phase of halite crystallization, which was also tested by a core from the upper Zechstein salt formation. Generally, the sequence of $\delta^{37} \mathrm{Cl}$ values in salt rock is halite $>$ sylvite $>$ carnallite. Hence, $\delta^{37} \mathrm{Cl}$ in salts can be used as an indicator of evaporation stage.

Finally, Li and Han (1995) carried out research on the distribution of oxygen isotopes of crystalline water in gypsum through experiments of $25^{\circ} \mathrm{C}$ isothermal evaporation of sea water from the South China Sea. The results showed that the value of $\delta^{18} \mathrm{O}$ increased correspondingly with the process of evaporation from $22.8 \%$ in gypsum at the beginning of precipitation to $28.6 \%$ at the end of gypsum precipitation. In the end stage of carnallite precipitation, the value of $\delta^{18} \mathrm{O}$ increased to $32.7 \%$. So the 


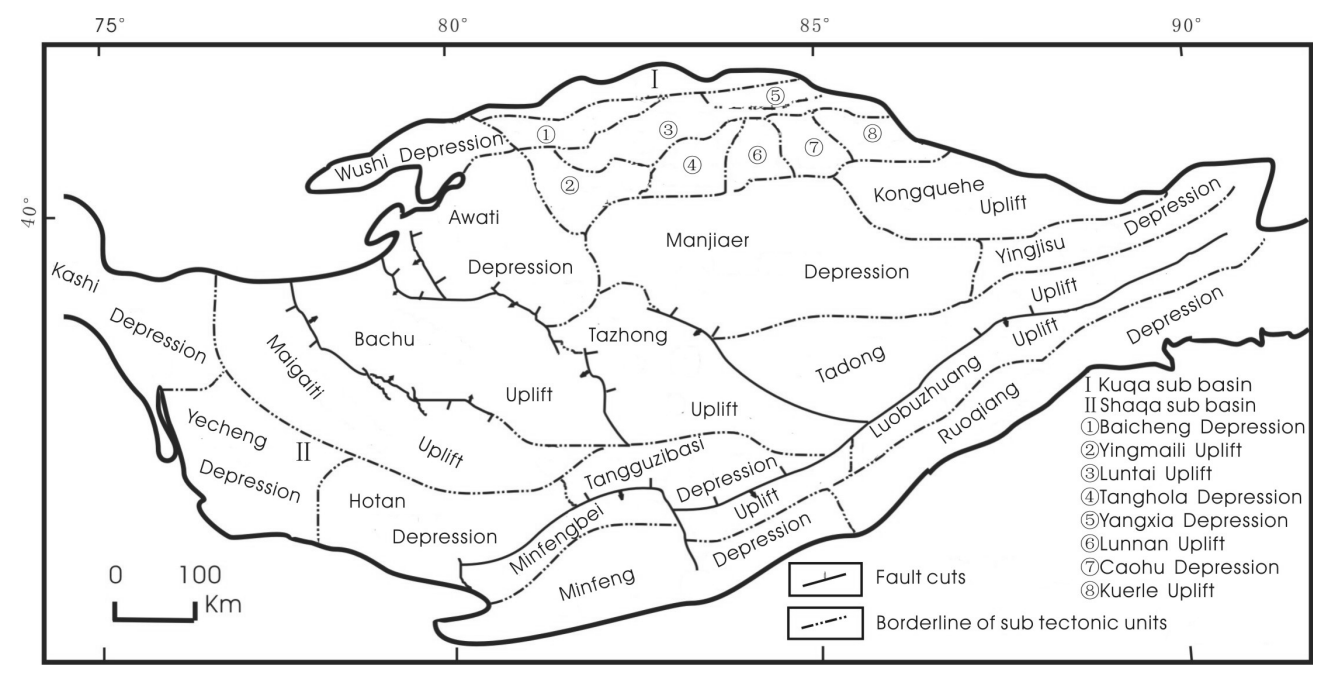

Fig. 2. Tectonic units in the Tarim Basin.

Table 1. Schematic stratigraphic logs of Kuqa and Shaqa sub-basin

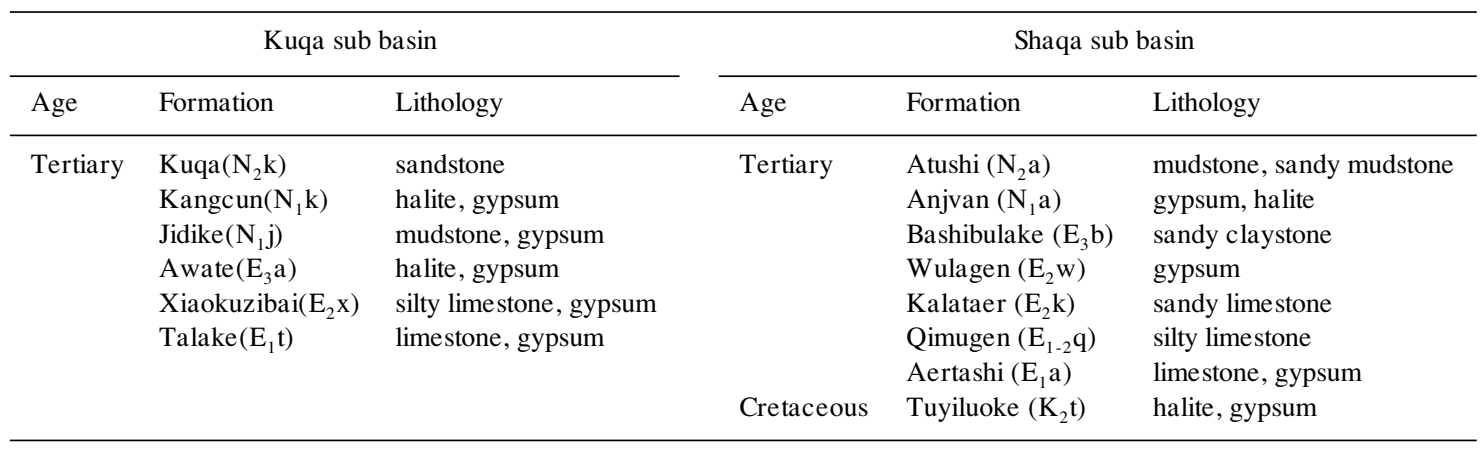

value of $\delta^{18} \mathrm{O}$ can also be used as a test for the evaporating concentration of the original brine from which the halite was formed.

\section{Geological Setting}

The Tarim Basin, located in Xinjiang province (Fig. $1)$, is the largest deposit basin in China with an area of about $560,000 \mathrm{~km}^{2}$. From the late Triassic to the early Miocene, two large sub-basins developed: the Kuqa subbasin at the foot of the Tianshan Mountains in the north and the Shaqa sub-basin at the foot of the Kunlun Mountains in the southwestern Tarim Basin (Fig. 2). During the late Cretaceous to the early Tertiary, the Tethys seawater repeatedly flooded into the Shaqa and the Kuqa sub-basins through the Awati strait (Guo, 1991; Hao et al., 1988). At the same time the tectonic activity (such as the Yanshan movement) caused the basin to be alternately raised and lowered and to break up into a series of subdepressions, such as the Kashi, Awati, Baicheng and
Yangxia depressions (Cai et al., 2001) (Fig. 2). The subsequent influx of seawater into many closed or half-closed basins, lagoons and salt lakes led to the region becoming an important salt rock deposit. Those are preserved as thick sequences of salt rock developed in Tertiary $\left(E_{1}\right.$ $\mathrm{N}_{1}$ ) strata (Xiaokuzibai formation, $\mathrm{E}_{2} \mathrm{x}$; Awate formation, $E_{3} a$; Kangcun formation, $N_{1} k$ ) throughout the middle and western regions of the Kuqa sub-basin, as well as late Cretaceous $\left(\mathrm{K}_{2}\right)$ strata (Tuyiluoke formation, $\mathrm{K}_{2} \mathrm{t}$ ) and late Tertiary strata (Anjvan formation, $\mathrm{N}_{1}$ a) in the western Shaqa sub-basin, such as the Kashi depression (Table 1). The adjacent Tadzhiki Basin, to the west of the Tarim Basin, has already been shown to contain a potash deposit formed during the Jurassic to Cretaceous periods. Both the western Tarim Basin and Tadzhiki Basins have similar geological characteristics and paleo-enviromental conditions since the Mesozoic, as they were connected by the Tethys (Qian et al., 1994). Hence, the western Tarim Basin likely contains the geological conditions necessary to yield potash deposits: (1) repeated seawater influx to 
Table 2. The analytical results of $\delta^{37} \mathrm{Cl}, \mathrm{Br} \times 10^{3} / \mathrm{Cl}, \delta^{34} \mathrm{~S}, \delta^{18} \mathrm{O}$ of salt rock, gypsum and crystalline water in the western Tarim Basin

\begin{tabular}{|c|c|c|c|c|c|c|}
\hline \multirow[t]{2}{*}{ Tectonic units } & \multirow[t]{2}{*}{ Salt mineral section } & \multirow[t]{2}{*}{ Formation (time) } & \multicolumn{4}{|c|}{ Geochemical characteristics } \\
\hline & & & $\begin{array}{c}\text { Salt rock } \\
\delta^{37} \mathrm{Cl}\end{array}$ & $\begin{array}{c}\text { Salt rock } \\
\mathrm{Br} \times 10^{3} / \mathrm{Cl}\end{array}$ & $\begin{array}{c}\text { Gypsum } \\
\delta^{34} \mathrm{~S}(\% o)\end{array}$ & $\begin{array}{c}\text { Crystalline water } \\
\delta^{18} \mathrm{O}(\% \circ)\end{array}$ \\
\hline \multirow[t]{18}{*}{ Kuqa sub-basin } & Tuzimaza & Awate $\left(\mathrm{E}_{3} \mathrm{a}\right)$ & 1.3 & 0.002 & & \\
\hline & Dawanqi & & 2.1 & 0.003 & & \\
\hline & Charqi & & 0.6 & 0.007 & & \\
\hline & Misikantake & & 0.8 & 0 & & \\
\hline & Yanshuigou & & 3.3 & 0 & & \\
\hline & Yanshankou & & 0.9 & 0.004 & 9.3 & \\
\hline & Yanshankouxi & & 1.9 & 0.006 & 12.4 & \\
\hline & Baozidun & & 0.9 & 0 & & \\
\hline & Tagelake & & 0.9 & 0.001 & 10.8 & 18.9 \\
\hline & Yanshan & & 0.4 & 0 & & \\
\hline & Nan Qa & & & & 11.8 & 23.2 \\
\hline & Tuziluoke & Kangcun $\left(\mathrm{N}_{1} \mathrm{k}\right)$ & & & 12.2 & \\
\hline & & & & & 12.1 & \\
\hline & & & & & 11.9 & \\
\hline & Yangxia & & & & 10.9 & \\
\hline & & & & & 12.6 & 27.1 \\
\hline & Weidong & & & & 12.3 & 21.6 \\
\hline & & & & & 12.3 & \\
\hline \multirow[t]{13}{*}{ Shaqa sub-basin } & Wulukeqiati & $\operatorname{Anjvan}\left(\mathrm{N}_{1} \mathrm{a}\right)$ & -0.3 & 0.004 & 14.6 & 14.2 \\
\hline & Kuoshitashi & Tuyiluoke $\left(\mathrm{K}_{2} \mathrm{t}\right)$ & 0 & 0.006 & 20.1 & 18.1 \\
\hline & & & & & 20.0 & \\
\hline & Wukeshaluxi & & -0.9 & 0.012 & 19.3 & \\
\hline & Wukeshuludong & & -1.2 & 0.044 & 19.7 & 29.7 \\
\hline & & & & & 19.3 & \\
\hline & Tashimilike & & -0.6 & 0.020 & 19.9 & 26.1 \\
\hline & & & & & 19.9 & \\
\hline & Shaman-upper & & & & 18.5 & 22.7 \\
\hline & Shaman-middle & & & & 18.4 & \\
\hline & Shaman-lower & & & & 18.4 & \\
\hline & Kuyakexi & Xiaohaizi $\left(\mathrm{C}_{2} \mathrm{x}\right)$ & -0.5 & 0.008 & & \\
\hline & Kuyakedong & & -0.7 & 0.025 & & \\
\hline \multirow{2}{*}{ Marine sulfate* } & Cretaceous & & & & $16.0 \sim 20.7$ & \\
\hline & Cenozoic & & & & $17.5 \sim 22.0$ & \\
\hline
\end{tabular}

*Data of marine sulfate-sulfur isotopes from Paytan et al. (1998, 2004).

allow for thick formations of salt rock; (2) several separate depressions and marginal fault basins to provide favorable tectonic conditions for the preservation of potash deposits; (3) long-periods of arid paleoclimate to provide a sustainable evaporative environment for salt precipitation. These observations suggest that the Kuqa and Shaqa sub-basins are promising areas in which to find ancient potash deposits.

\section{Sample Collection and Measurements}

Since 2002, we have carried out 5 field surveys on nearly 30 sections of ancient evaporites (particularly halite deposits) in the western Tarim Basin (Fig. 1) and collected about 300 gypsum and halite samples from the
Awati depression $\left(E_{3} a\right)$, Baicheng depression $\left(E_{3} a\right)$, Yangxia depression $\left(\mathrm{N}_{1} \mathrm{j}\right)$ in the Kuqa sub-basin and the Kashi depression $\left(\mathrm{K}_{2} \mathrm{t}, \mathrm{N}_{1} \mathrm{a}\right)$ in the Shaqa sub-basin (Fig. 2).

Before analysis of the samples, we carefully picked pure halite and gypsum crystals under a microscope. We then determined the chlorine isotope composition and $\mathrm{Br}^{-}$ and $\mathrm{Cl}^{-}$concentrations of halite, the sulfur isotope composition of gypsum and the oxygen isotope composition of crystalline water. The analytical methods are as follows:

a) $\mathrm{Br}^{-}$and $\mathrm{Cl}^{-}$concentrations in the halite: firstly the pure halite samples were dissolved in distilled pure water and then chloramines $\mathrm{T}$ was utilized as an oxidant and fluorescein as a chromogenic reagent. In the weak acid 
solution, there is a chemical reaction between $\mathrm{Br}$ and fluorescein to yield strong absorption at $510 \mathrm{~nm}$ wavelength that was measured using a spectrophotometer (VIS7200 type). The $\mathrm{Cl}$ content of the halite was determined by the $\mathrm{AgNO}_{3}$ method of titration. The precision of the $\mathrm{Br}^{-}$and $\mathrm{Cl}^{-}$analysis was about $1 \%$.

b) Chlorine isotope measurement: The fractionation of chlorine isotopes in nature is relatively small because chlorine generally forms electrostatic bonds and does not exhibit changes in valence state. The range of chlorine isotope compositions ( $\delta^{37} \mathrm{Cl}$ values) in natural samples is only about $15 \%$ (Coplen et al., 2002). Therefore, the analytical errors can mask the geological information recorded by chlorine isotopes if the experimental precision is not high. In order to avoid any potential contamination during our analytical procedure, we carefully picked out pure particles of salt minerals under a microscope and then dissolved them (the $\mathrm{Cl}^{-}$content is about $10 \mathrm{mg} / \mathrm{mL}$ ) with high-purity water produced by sub-boiling distillation. Secondly, we passed the sample solution through a Ba-resin column to remove interfering $\mathrm{SO}_{4}{ }^{2-}$, followed by passage through an $\mathrm{H}$-resin column to remove cations and convert the $\mathrm{Cl}^{-}$into $\mathrm{HCl}$. Finally, the pure $\mathrm{HCl}$ solution was passed through a Cs-resin to produce a $\mathrm{CsCl}$ solution. The $\mathrm{CsCl}$ solution was then used for the mass spectrometry analysis. The mass spectrometry analysis is basically the same as that reported by Xiao and Zhang (1992); Xiao et al. (1995) and Vengosh et al. (1989): A VG 354 thermal ionization mass spectrometer was used for chlorine isotope measurements. The single tantalum filament heated at a current of $3.0 \mathrm{~A}$ for $1 \mathrm{~h}$ in a vacuum system, was first treated with a graphite slurry of $3 \mu \mathrm{L}$ to coat the center of the filament. The sample solution, about $10 \mu \mathrm{g} \mathrm{Cl}$ as $\mathrm{CsCl}$, was loaded when the graphite was near to dryness and then dried by passing a current of $1.0 \mathrm{~A}$ through the filament for $5 \mathrm{~min}$. The sample was then loaded into the mass spectrometer for automatic analysis (Table 2). The isotope standard is the secondary isotopic reference material of GSB-01-1630-2003 NaCl offered by Xiao et al. (2002a). An average value of $0.319256 \pm$ $0.000045(2 \sigma, n=14)$ of the ${ }^{37} \mathrm{Cl} /{ }^{35} \mathrm{Cl}$ ratio was obtained through repeated analysis under the same condition as the sample analysis. The $\delta^{37} \mathrm{Cl}$ values are calculated from the following formula:

$$
\begin{aligned}
\delta^{37} \mathrm{Cl}= & {\left[\left({ }^{37} \mathrm{Cl} /{ }^{35} \mathrm{Cl}\right)_{\text {sample }}-\left({ }^{37} \mathrm{Cl} /{ }^{35} \mathrm{Cl}\right)_{\text {standard }}\right] } \\
& \times 1000 /\left({ }^{37} \mathrm{Cl} /{ }^{35} \mathrm{Cl}\right)_{\text {standard }},
\end{aligned}
$$

where $\left({ }^{37} \mathrm{Cl} /{ }^{35} \mathrm{Cl}\right)_{\text {standard }}=0.319256 \pm 0.000045$.

c) Sulfur isotope measurement (Holser and Kaplan, 1966): Pure gypsum crystals were picked under a microscope and then rinsed quickly with pure water. After drying and grinding, the powder was melted to form $\mathrm{BaSO}_{4}$ through adding carbonate and zinc oxide. After that, the
$\mathrm{BaSO}_{4}$ was converted into $\mathrm{SO}_{2}$ gas by adding $\mathrm{V}_{2} \mathrm{O}_{5}$ at temperatures of $1050^{\circ} \mathrm{C}$. The gas was then directly guided into a mass spectrometer (MAT251) to measure the $\delta^{34} \mathrm{~S}$ value. The precision of the whole analytical procedure was $0.2 \%$. The values of $\delta^{34} \mathrm{~S}$ were calculated from the following formula:

$$
\begin{aligned}
\delta^{34} S= & {\left[\left({ }^{34} S /{ }^{32} S\right)_{\text {sample }}-\left({ }^{34} S /{ }^{32} S\right)_{\text {standard }}\right] } \\
& \times 1000 /\left({ }^{34} S /{ }^{32} S\right)_{\text {standard }}
\end{aligned}
$$

where $\left({ }^{34} \mathrm{~S} /{ }^{32} \mathrm{~S}\right)_{\text {standard }}=0.0450045 \pm 0.0000093$ (the international standard value of CDT).

d) Oxygen isotope measurement of crystalline water in gypsum: Pure and primary sedimentary gypsum crystals $\left(\mathrm{CaSO}_{4} \cdot 2 \mathrm{H}_{2} \mathrm{O}>95 \%\right)$ deposited in or near to the halite strata were picked, mainly from the Kashi depression $\left(K_{2} t\right)$ in the Shaqa sub-basin, the Awati depression $\left(E_{3} s\right)$, and the Yangxia Depression $\left(\mathrm{N}_{1} \mathrm{j}\right)$ in the Kuqa sub-basin. The samples were dried first at low temperatures (less than $60^{\circ} \mathrm{C}$ ) for about 24 hours in order to completely remove surface adsorptive water and then quickly dehydrated to release all the crystalline water at more than $600^{\circ} \mathrm{C}$. The dehydrated water was reacted with hydrochloride guanidine and turned into $\mathrm{CO}_{2}$. The $\mathrm{CO}_{2}$ was directly guided into a mass spectrometer (MAT251) to measure the $\delta^{18} \mathrm{O}$ value (Table 2) (Zhang et al., 1990). The precision of the whole procedure is about $0.05 \%$.

\section{RESULTS AND DISCUSSIONS}

Characteristics of sulfur isotope distributions and indications for facies of evaporite deposits

From the sulfur isotope results (Table 2), the $\delta^{34} \mathrm{~S}$ values in gypsum all showed low and positive values (Fig. 3 ). The values center around 10 to $20 \%$ and the highest value is only $20.1 \%$, suggesting that the deposition of sulfides within sediments of these basins was not important (Makhnach et al., 2000). During the Cretaceous, the secular variations in $\delta^{34} \mathrm{~S}$ in seawater changed between 16 and $22 \%$. Therefore, the distribution of sulfur should mainly be determined by the source of sulfur. The late Cretaceous strata named Tuyiluoke Formation $\left(\mathrm{K}_{2} \mathrm{t}\right)$ in the Kashi depression clearly has higher values (ranging from $15 \%$ to $20 \%$ and the average value is $18 \%$ ) than those in the Tertiary strata in the Kashi or Kuqa depression and also very close to the values of the Cretaceous sea water sulfate $(18 \%$ ). In the Tertiary strata of the Kashi depression, the values of $\delta^{34} \mathrm{~S}$ in the Anjvan Formation $\left(\mathrm{N}_{1}\right.$ a) are less than $15 \%$ out more than $10 \%$, which suggests that the sulfate source was the product of continental or mixed-water precipitation because these values are much lower than those for Tertiary seawater. The lower bromine content of halite or the ratio of $\mathrm{Br} \times 10^{3} / \mathrm{Cl}$ in the Anjvan Formation also confirms the character of non- 


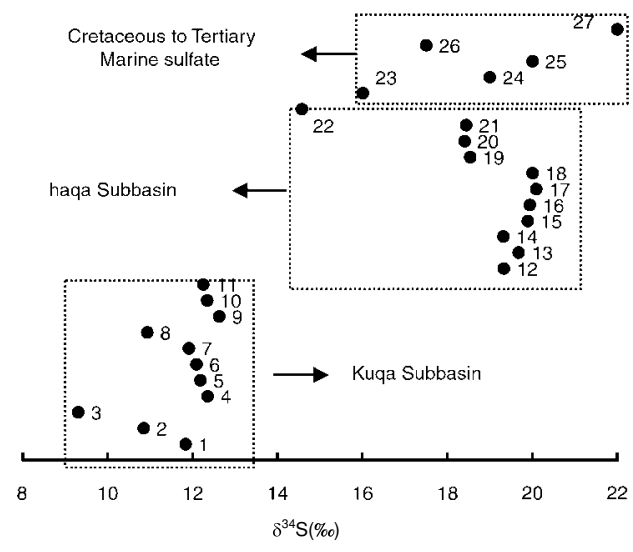

Field No.
NK01
TGLK01
YSK-4-01
YSK-4-02
TZLK-01
TZLK-05
TZLK-05
YX-4-01
YX-4-02
WDMK-01
WDMK-02
WKSLO1
WKSL02
WKSL03
TSMLK01

Fig. 3. Sulfur isotope distribution in gypsum in salt sections in the western Tarim Basin (sample 1-11 from the Tertiary strata $\left(E_{3} a\right)$ in the Kuqa sub-basin; Sample 12-20 from the late Cretaceous strata $\left(K_{2} t\right)$ and sample 22 from the Tertiary strata $\left(N_{l} a\right)$ in the Shaqa sub-basin; data 23-27 is the marine sulfate-sulfur isotope from the Cretaceous to Tertiary (Paytan et al., 1998, 2004).

marine sedimentary facies. In the Kuqa sub-basin, all values of $\delta^{34} \mathrm{~S}$ in gypsum are lower than $15 \%$ and close to the values of Tertiary gypsum in the Kashi depression, which again suggests that the origin of sulfur in the salt rock is mixed continental and marine water. The average value of $\delta^{34} \mathrm{~S}$ is $12.5 \%$ in the Awati depression of western and $12.1 \%$ in the Yangxia depression of the eastern Kuqa sub-basin, respectively. Hence, the late Cretaceous salt rock represents a marine-sourced deposit while the early Tertiary salt rocks either in the Shaqa sub-basin or the Kuqa sub-basin have had a strong influence of local continentally derived sulfur. While the sea water had initially flooded into the Kuqa sub-basin and brought much salt source, more fresh water from a continental source in the Tianshan Mountain later mixed with sea water and completely changed the original salts sedimentary environment into a continental environment. From the point of view of lithofacies-paleogeography, the Kashi depression is adjacent to the Middle Asia potash deposit basin and becomes a channel of the Tethyan sea water influx or outflow. The origin of the brines from which the evaporative sediments have formed, was therefore mainly

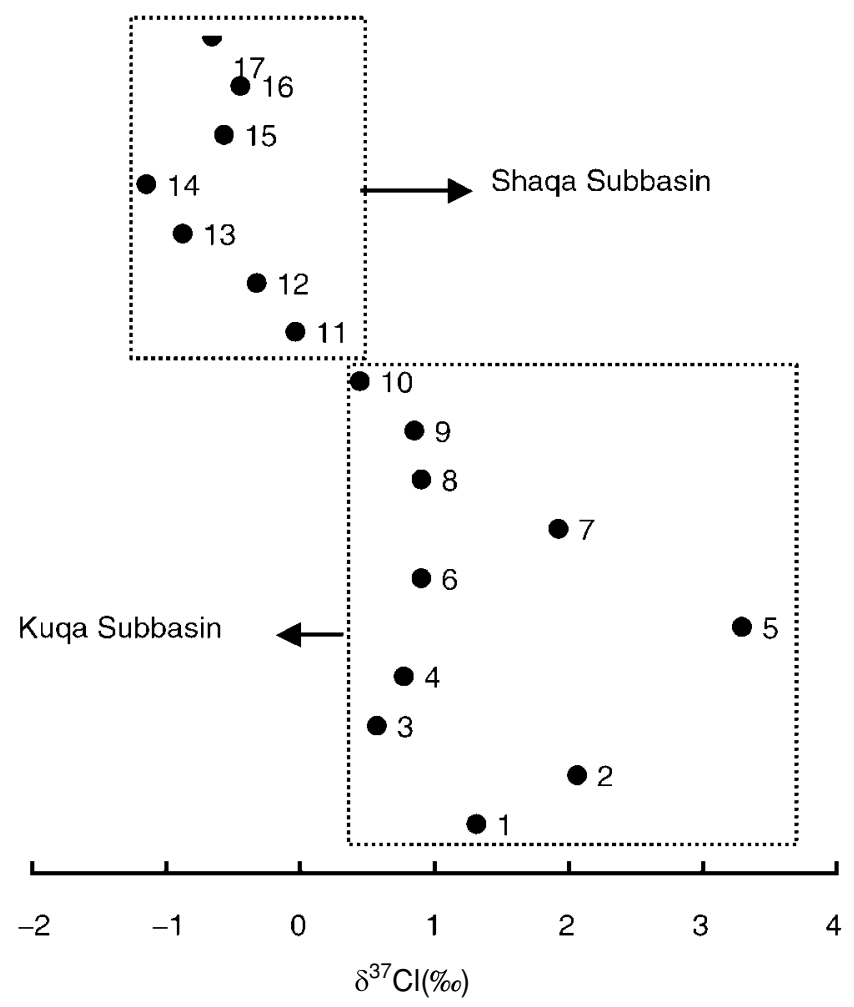

$\begin{array}{lccl}\text { Field No. } & \text { Samp. No } & \delta^{37} \mathrm{Cl} & \mathrm{Br} \times 10^{3} / \mathrm{Cl} \\ \text { Tuzimaza } & 1 & 1.31 & 0.002 \\ \text { Dawanqi } & 2 & 2.06 & 0.003 \\ \text { Charqi } & 3 & 0.57 & 0.007 \\ \text { Msikantake } & 4 & 0.77 & 0 \\ \text { Yanshuigou } & 5 & 3.29 & 0 \\ \text { Yanshankou } & 6 & 0.9 & 0.004 \\ \text { Yanshuigouxi } & 7 & 1.92 & 0.006 \\ \text { Baozidun } & 8 & 0.9 & 0 \\ \text { Tagelake } & 9 & 0.85 & 0.001 \\ \text { Yanshan } & 10 & 0.44 & 0 \\ \text { Kuoshitashi } & 11 & 0.04 & 0.006 \\ \text { Wulukeqiati } & 12 & 0.33 & 0.004 \\ \text { Wukeshaluxi } & 13 & -0.88 & 0.012 \\ \text { Wukeshludong } & 14 & -1.15 & 0.044 \\ \text { Tshimilike } & 15 & -0.57 & 0.02 \\ \text { Kuyakexi } & 16 & -0.45 & 0.008 \\ \text { Kuyakedong } & 17 & -0.66 & 0.025 \\ \text { Salt (sea water) } & 18 & 0 & 0.11\end{array}$

Fig. 4. Chlorine isotope distribution in ancient halite in the western Tarim Basin (sample 1-10 from the Kuqa sub-basin and 11-17 from the Shaqa sub-basin).

marine-sourced, but the Kuqa sub-basin developed inland and a smaller amount of sea water had flooded into it mixed with more like continental water. So the sedimentary facies was more like a continental or mixed deposit. 
Chlorine isotope distribution in salt rock and sedimentary stage

We analyzed chlorine isotope compositions in salt rock samples from 15 sections in the Kuqa and Shaqa sub-basin. The results showed that the $\delta^{37} \mathrm{Cl}$ values of the salt rock are a valid index to indicate whether the potash deposits are located in regions with low $\mathrm{Br}$ background contents, such as the Tarim Basin.

The $\delta^{37} \mathrm{Cl}$ values (Fig. 4) show that all values of samples from the Shaqa sub-basin are clearly negative (the range is $-1.2 \%$ to $0 \%$, average value is $-0.6 \%$ ) and, samples from the Kuqa sub-basin are positive (the range is $0.4 \%$ o to $3.3 \%$, average value is $1.3 \%$ ). In the Shaqa subbasin, $\mathrm{Br} \times 10^{3} / \mathrm{Cl}$ ratios (Fig. 5) in salt rock lie in the range 0.004 to 0.044 (average 0.017) and in the Kuqa subbasin the ratios are between 0 and 0.005 (average 0.001 ) in salt rock samples. Although the $\mathrm{Br} \times 10^{3} / \mathrm{Cl}$ ratios are very low, they are generally higher in the Shaqa sub-basin than in the Kuqa sub-basin, indicating that the more negative the $\delta^{37} \mathrm{Cl}$ value, the higher the $\mathrm{Br} \times 10^{3} / \mathrm{Cl}$ ratio is in salt rocks. This is particularly evident for salt rock samples from the Kashi depression of the Wukeshalu salt section (Fig. 1) in the western Shaqa sub-basin, where the $\mathrm{Br} \times 10^{3} / \mathrm{Cl}$ ratios (0.044) are the highest (Fig. 5) in the Tarim Basin, and the $\delta^{37} \mathrm{Cl}$ values in this section are the most negative $(-1.2 \%$ ) (Fig. 4$)$. The highest value of the $\mathrm{Br} \times 10^{3} / \mathrm{Cl}$ ratio in all samples is only 0.044 (generally they are less than 0.010 ), which is nearly 10 times lower than the early precipitation salts from seawater (generally it is >0.01) (Fig. 5) (McCaffrey et al., 1987). Overall, the $\mathrm{Br} \times 10^{3} / \mathrm{Cl}$ ratio is generally 10 times lower for salt rock samples from the Shaqa sub-basin and 100, or even 1000 times lower from the Kuqa sub-basin than that of precipitation salts from seawater (0.110 1.030). Thus it can be seen that the phenomenon of huge thick salt strata deposit with evidently low $\mathrm{Br} \times 10^{3} / \mathrm{Cl}$ ratio cannot be explained by a common model of marine sediment. Besides, due to high errors and difficulties to measure extra low content of $\mathrm{Br}$ (generally about $10^{-6}$ ) in salt rock samples, there appeared to be some disagreement in the fluctuations of $\delta^{37} \mathrm{Cl}$ value and $\mathrm{Br} \times 10^{3} / \mathrm{Cl}$ ratios. It will thus be difficult to find a geochemical distribution rule for salt rock formation and obtain reliable evidences if we follow usual procedures and depend on the $\mathrm{Br} \times$ $10^{3} / \mathrm{Cl}$ ratio to guide us in locating potash deposits. Our research results showed that only those samples with the $\mathrm{Br} \times 10^{3} / \mathrm{Cl}$ ratios higher than 0.010 had a clear correlation with $\delta^{37} \mathrm{Cl}$ values (Table 2). As for why the $\mathrm{Br} \times 10^{3}$ / $\mathrm{Cl}$ ratios are so low in these deposits despite sulfur isotope evidence for a marine origin of the Cretaceous sediments, is unclear at the present time. We suggest that the $\mathrm{Br}$ concentration in ancient Tethyan water could have been low because many Tethyan water sourced salt rock sections have low $\mathrm{Br}$ content (e.g., Liu et al., 1997). Fur-

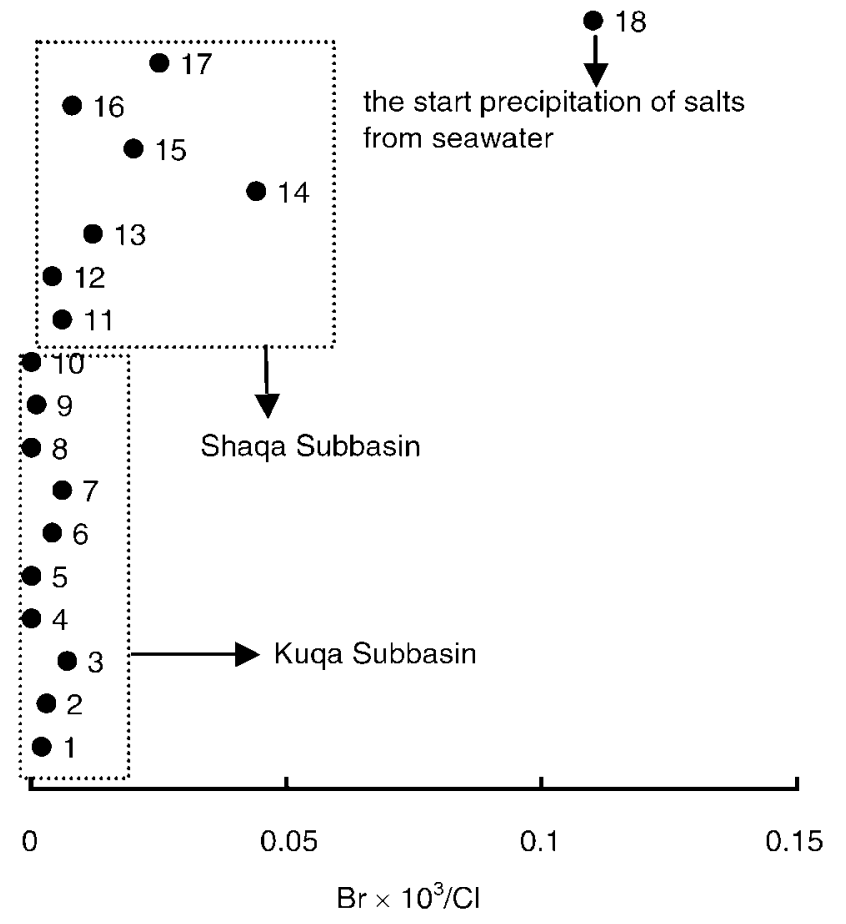

$\begin{array}{lccc}\text { Field No. } & \text { Samp. No } & \delta^{37} \mathrm{Cl} & \mathrm{Br} \times 10^{3} / \mathrm{C} \\ \text { Tuzimaza } & 1 & 1.31 & 0.002 \\ \text { Dawanqi } & 2 & 2.06 & 0.003 \\ \text { Charqi } & 3 & 0.57 & 0.007 \\ \text { Msikantake } & 4 & 0.77 & 0 \\ \text { Yanshuigou } & 5 & 3.29 & 0 \\ \text { Yanshankou } & 6 & 0.9 & 0.004 \\ \text { Yanshuigouxi } & 7 & 1.92 & 0.006 \\ \text { Baozidun } & 8 & 0.9 & 0 \\ \text { Tagelake } & 9 & 0.85 & 0.001 \\ \text { Yanshan } & 10 & 0.44 & 0 \\ \text { Kuoshitashi } & 11 & 0.04 & 0.006 \\ \text { Wulukeqiati } & 12 & 0.33 & 0.004 \\ \text { Wukeshaluxi } & 13 & -0.88 & 0.012 \\ \text { Wukeshludong } & 14 & -1.15 & 0.044 \\ \text { Tshimilike } & 15 & -0.57 & 0.02 \\ \text { Kuyakexi } & 16 & -0.45 & 0.008 \\ \text { Kuyakedong } & 17 & -0.66 & 0.025 \\ \text { Salt (sea water) } & 18 & 0 & 0.11\end{array}$

Fig. 5. $\mathrm{Br} \times 10^{3} / \mathrm{Cl}$ ratios in ancient halite in the western Tarim Basin (sample 1-10 from the Kuqa sub-basin and 11-17 from the Shaqa sub-basin; 18 is the point of the start precipitation of salts from seawater).

thermore, diagenesis and recrystallization may also result in bromine concentrations decreasing in the salt rock.

From the characteristics of $\delta^{37} \mathrm{Cl}$ values and comparable relation with $\mathrm{Br} \times 10^{3} / \mathrm{Cl}$ ratios, we know that the $\delta^{37} \mathrm{Cl}$ values of salt rocks are clearly more negative in the 


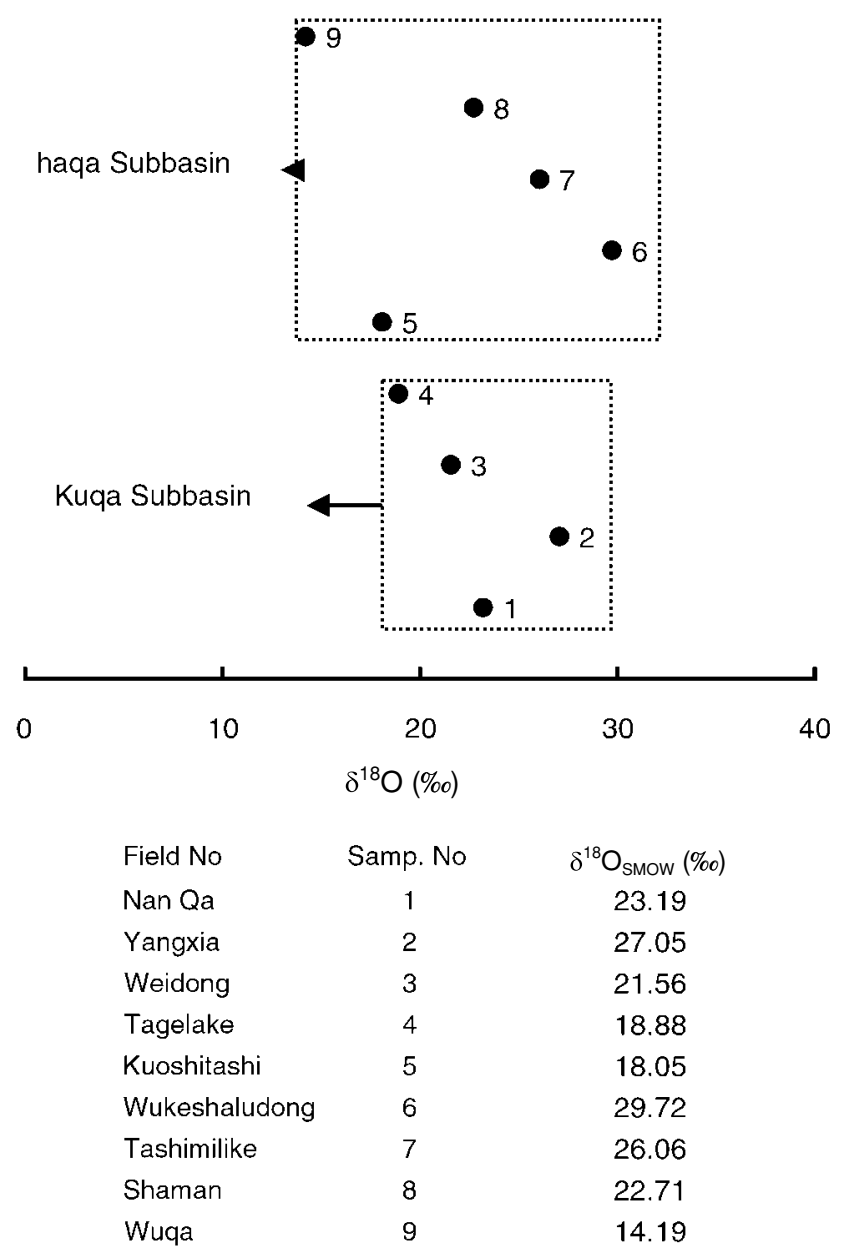

Fig. 6. Oxygen isotope compositions in crystalline water of gypsum in the Tarim Basin (sample 1-4 from Awate Formation $\left(N_{l} k\right)$ in the Kuqa sub-basin; sample 9 from the strata of Anjvan Formation $\left(N_{l} a\right)$ and 5-8 from the Tuyiluoke Formation $\left(K_{2} t\right)$ in the Shaqa sub-basin).

Shaqa sub-basin than in the Kuqa sub-basin, supporting the $\mathrm{S}$-isotope results in that they both suggest a higher proportion of marine water in the Shaqa sub basin. We conclude that the primitive brine that formed the salt rock in the Shaqa sub-basin was more concentrated than that in the Kuqa sub-basin. Besides, there may also have been more fresh water added to seawater in the Kuqa sub-basin, which possibly made the value of chlorine more positive (e.g., Xiao et al., 2002b). For example, analyses of the Pacific water and Changjiang estuary mixed fresh and brine water show that the $\delta^{37} \mathrm{Cl}$ value of the former sample is more negative than the latter, whose values range from about -0.5 to $0.6 \%$ (average $0 \%$ ) and 0.5 to $0.9 \%$ (average $0.6 \%$ ), respectively (Xiao et al., 2002b). Moreover, the $\delta^{37} \mathrm{Cl}$ values are the lowest for salt rock samples from the Kashi depression of the western Shaqa sub- basin, suggesting that the amount of sea water for the original brine was very high. Analyses of $\delta^{37} \mathrm{Cl}$ values of the world sylvite and salt deposits (Sun et al., 1998) show that $\delta^{37} \mathrm{Cl}$ values are commonly less than $-0.3 \%$ o for salt samples collected from above or below the potash strata and less than $-0.6 \%$ o for sylvite or less than $-1.0 \%$ for carnallite. This suggests that the Kashi depression of the western Shaqa sub-basin is a promising section for potash deposit formation, which is also verified by geological research. In the five sections of salt rock deposits in the Kashi Depression we studied, the highest $\delta^{37} \mathrm{Cl}$ value is $-0.3 \%$, the lowest value is $-1.2 \%$ and average is $-0.7 \%$. Therefore, we believe that this salt was more likely precipitated during the later stage of evaporation, possibly during the stage of potash deposit. Hence, it should be possible to find potash deposits in the Kashi depression.

Oxygen isotope distribution of crystalline water in gypsum and indication on concentration of original brine

The $\delta^{18} \mathrm{O}$ values of crystalline water in gypsum in the western Tarim Basin of Tuyiluoke formation $\left(\mathrm{K}_{2} \mathrm{t}\right)$ in the Kashi depression are higher (ranging from $22.7 \%$ to 29.7\%o, average 24.1\%o) than those in the Awati depression (ranging from $18.9 \%$ to $23.2 \%$ ) and the Yangxia depression (21.6\%o to 27.1\%o) (Table 2, Fig. 6). Hence, like the $\delta^{37} \mathrm{Cl}$, the $\delta^{18} \mathrm{O}$ values in these salt sections or formations also confirm that the salt rock deposited in the Kashi depression was the late stage of mineral precipitation.

\section{CONCLusions}

1) Sulfur isotope compositions of gypsum samples collected from the western Tarim Basin suggest that the late Cretaceous salt rock deposited in strata of the Tuyiluoke formation $\left(\mathrm{K}_{2} \mathrm{t}\right)$ was deposited in a full marine facies. By contrast, the Tertiary salt rocks in the Shaqa or the Kuqa sub-basin were closer to continental or mixed sea water/fresh water facies in terms of their depositional environment.

2) The chlorine isotope compositions $\left(\delta^{37} \mathrm{Cl}\right)$ of halite and oxygen isotope compositions $\left(\delta^{18} \mathrm{O}\right)$ of gypsum crystalline water are better proxies to evaluate the sedimentary stage of the ancient salt minerals. In agreement with the $\mathrm{Br} \times 10^{3} / \mathrm{Cl}$ ratio of halite, we can confirm that the late Cretaceous salt rock in strata of the Tuyiluoke formation was $\left(\mathrm{K}_{2} \mathrm{t}\right)$ deposited later than other salt rocks, such as those deposited in the Awati depression in the western, the Baicheng depression in the middle and the Yangxia depression in the eastern Kuqa sub-basin. Moreover, in some areas of salt rock deposition, such as the Wukeshalu salt section in the Kashi depression, the original brine from which the wide and thick halite was formed 
had possibly reached the late stage of sylvite precipitation.

3) From the prospective of space and time, the Kashi depression in the western Tarim Basin is the most favorable area to include potash deposits, and the late Cretaceous strata of the Tuyiluoke formation $\left(K_{2} t\right)$ is the most promising strata in which to find potash deposits.

Acknowledgments - We thank Professor Xiao Yingkai and his group members for their kind assistance in sample analysis and all members of our group for field works. We also should thank Professor Suzanne Leroy, Martin R. Palmer and other reviewers or editors for their careful revisions to the paper and good suggestions. This study was partially supported by the National Key Technologies R \& D Program.

\section{REFERENCES}

Bloch, M. R. and Schnerb, J. (1953) On the $\mathrm{Cl}^{-} / \mathrm{Br}^{-}$ratio and the distribution of $\mathrm{Br}$ ions in liquids and solids during evaporation of bromide-containing chloride solutions. Bull. Res. Council Isr, 151-158.

Cai, C., Franks, S. G. and Aagaard, P. (2001) Origin and migration of brines from Paleozoic strata in Central Tarim, China: constraints from ${ }^{87} \mathrm{Sr} /{ }^{86} \mathrm{Sr}, \delta \mathrm{D}, \delta^{18} \mathrm{O}$ and water chemistry. Appl. Geochem. 16, 1269-1284.

Coplen, T. B., Hopple, J. A., Böhlke, J. K., Peiser, H. S., Rieder, S. E., Krouse, H. R., Rosman, K. J. R., Ding, T., Vocke, R. D., Jr., Revesz, K. M., Lamberty, A., Taylor, P. and De Bievre, P. (2002) Compilation of minimum and maximum isotope ratios of selected elements in naturally occurring terrestrial materials and reagents. U.S. Geological Survey Water-Resources Investigations Report 56.

Eggenkamp, H. G. M. and Kreulen, R. (1995) Chlorine stable isotopic fractionation in evaporates. Geochim. Cosmochimi. Acta 59(24), 5169-5175.

Guo, X. (1991) The depositional environment of the Cretaceous Kezilsu Group in Xinjiang-with a discussion of the lowermost marine horizon of the Cretaceous in the Western Tarim Basin. Acta Geolog. Sinica 4(4), 441-454.

Hao, Y., Zeng, X. and Guo, X. (1988) The marine Cretaceous in the Western part of the Tarim Basin of Xinjiang and its depositional environments. Acta Geol. Sinica 1(1), 13-27.

Holser, W. T. and Kaplan, J. R. (1966) Isotope geochemistry of sedimentary sulfates. Chem. Geol. 1, 93-135.

Li, Y. and Han, W. (1995) Experimental study of $25^{\circ} \mathrm{C}$ isothermal evaporation of sea water from the south China sea. Scientia Geologica Sinica 30(3), 233-239 (in Chinese).

Liu, Q., Du, Z. and Chen, Y. (1997) Potash Salt-Searching Prospects in Northern Shanxi Ordovician and Tarim Carboniferous. Atomic Energy Press, Beijing, 198-205 (in Chinese).

Liu, W., Xiao, Y., Wang, Q., Qi, H., Wang, Y., Zhou, Y. and Shirodkar, P. V. (1997) Chlorine isotopic geochemistry of salt lakes in the Qaidam Basin, China. Chem. Geol. 136, 271-279.

Makhnach, A., Mikhajlov, N., Kolosov, I., Gulis, L., Shimanovich, V. and Demeneva, O. (2000) Comparative analysis of sulfur isotope behavior in the basins with evaporites of chloride and sulfate types. Sediment. Geol. 134, 343-360.

McCaffrey, M. A., Lazar, B. and Holland, H. D. (1987) The evaporation path of seawater and coprecipitation of $\mathrm{Br}^{-}$and $\mathrm{K}^{+}$with halite. J. Sediment. Petrol. 57, 928-937.

Mekhtieva, V. L. (1980) Sulfur isotopic composition of sediments and brines of modern and ancient Kara-BogazGol. Geokhimija 5, 745-752.

Paytan, A., Kastner, M., Campbell, D. and Thiemens, M. H. (1998) Sulfur isotopic composition of Cenozoic seawater sulfate. Science 282(5393), 1459-1462.

Paytan, A., Kastner, M., Campbell, D. and Thiemens, M. H. (2004) Seawater sulfur isotope fluctuations in the Cretaceous, Science 304(5677), 1663-1665.

Philips, F. M. and Bentley, H. W. (1987) Isotopic fractionation during ion filtration. Geochim. Cosmochim. Acta 1087(51), 683-695.

Qian, Z., Qu, Y. and Liu, Q. (1994) Sylvinite Deposit. Geological Publishing House, Beijing, 189-203 (in Chinese).

Sun, D., Shui, K., Gao, J., Liu, W., Zhou, Y. and Ma, Y. (1998) A preliminary investigation on stable isotopic geochemistry of chlorine for the sylvinite deposits of chloride-type. Geoscience 12(2), 229-234 (in Chinese).

Tan, H., Ma, H., Xiao, Y., Wei, H., Zhang, X. and Ma, W. (2005) Characteristics of chlorine isotope distribution and analysis on sylvinite deposit formation based on ancient salt rock in the western Tarim Basin. Science in China Series D-Earth Sciences 48(11), 1913-1920.

Vengosh, A., Chivas, A. R. and McCullonch, M. T. (1989) Direct determination of boron and chlorine isotopes in geological materials by negative thermal-ionization mass spectrometry. Chem. Geol. 79, 333-343.

Wedepohl, K. H. (ed.) (1978) Isotope in nature. Handbook of Geochemistry, 1-40.

Xiao, Y. and Zhang, C. (1992) High precision isotopic measurement of chlorine by thermal ionization mass spectrometry of the $\mathrm{Cs}_{2} \mathrm{Cl}^{+}$ion. Int. J. Mass Spectrom. Ion Processes 116, 183-192.

Xiao, Y., Zhou, Y. and Liu, W. (1995) Precise measurement of chlorine isotopes based $\mathrm{Cs}_{2} \mathrm{Cl}^{+}$by thermal ionization mass spectrometry. Anal. Lett. 28, 1295-1300.

Xiao, Y., Liu, W., Zhou, Y. and Wang, Y. (1999) Variations of isotopic compositions of chlorine in evaporation-controlled salt lake brine of Qaidam Basin, China. Chinese Journal of Oceanology and Limnology, 2000 18(2), 169-177.

Xiao, Y., Zhou, Y. and Liu, W. (2002a) Characters of chlorine isotopic composition of seawater. Geol. Rev. 48(App.), 264270.

Xiao, Y., Zhou, Y. and Wang, Q. (2002b) A secondary isotopic reference material of chlorine from selected seawater. Chem. Geol. 182, 655-661.

Zhang, B., Fan, H. and Zhang, P. (1990) Hydrogen and oxygen stable analysis of fluid inclusions in halite in Charhan Salt Lakes with geochemical implications. Acta Sedimentologica Sinica 8(1), 9-15 (in Chinese).

Zhen, M., Liu, W. and Xu, D. (1974) Research on periods and area for salt rock or sylvinite deposit formation in China. Geol. Min. Res. 1, 117-123 (in Chinese). 